\title{
ALGUMAS CONSIDERAÇÕES SOBRE O MAGISTÉRIO PONTIFÍCIO PARA AS MISSÕES ANTERIOR AO II CONCÍLIO DO VATICANO (1919-1959)
}

Some considerations on the Pontifical Magistery for missions before the II Vatican Concilium (1919-1959)

\section{Nuno Fernando de Pinho e Silva de Almeida Falcão*}

Resumo:A Igreja católica assume-se como uma instituição de vocação missionária. Este ideal, que pertence ao seu corpo de doutrina, teve ao longo do séc. XX uma atenção consistente e continuada dos Papas, que sobre a missão constituíram um Magistério Pontifício.

Este artigo faz uma breve análise desse magistério no período que medeia entre a encíclica de Bento XV Maximum Illud (1919) e o II Concílio do Vaticano, onde todo este magistério culmina no decreto conciliar Ad Gentes, que por sua vez será a influência fundamental do magistério sequente. Procurar-se-á destacar o papel deste magistério na transformação do pensamento missiológico, em particular no que se refere à formação de dioceses e de um clero naturais dos territórios de missão.

Palavras-chave: Papado, Magistério Pontifício, Missões

Abstract: The Catholic Church is an institution whit missionary vocation. This ideal, which belongs to its body of doctrine, had throughout the XX century a consistent and continuous attention of the Popes, who constituted a Pontifical Magisterium about the missions.

This article gives a brief analysis of this magisterium in the period between the encyclical of Pope Benedict XV Maximum Illud (1919) and the Second Vatican Council, where all this magisterium culminates in the conciliar decree Ad Gentes, which in turn will be the fundamental influence of the following magisterium. It will be emphasized the role of this magisterium in the transformation of the missiological thought, in particular as regards the formation of dioceses and a clergy in the territories of mission.

Keywords: Papacy, Pontifical Magisterium, Mission

\section{A IGREJA MISSIONÁRIA: DOUTRINA}

O estudo histórico das missões católicas, em África ou em qualquer outra geografia, é (e deve ser) antes de mais e principalmente um estudo dos seus contextos, dos seus processos, dos seus agentes e das sociedades em que se inserem.

Estamos a falar de uma realidade histórica que nos apresenta missionários e missionados como sujeitos de um diálogo particular, em jeito de mediação, o que obriga o investigador a colocar um conjunto complexo de questões para análise. Esta é a fortuna, a complexidade e a dificuldade de trabalhar o tema das missões, pela diversidade de fios que compõem este tecido histórico específico.

\footnotetext{
* Doutor em História e Investigador Integrado do Centro de Investigação Transdiciplinar Cultura, Espaço e Memória da Universidade do Porto (Portugal).
} 
Este texto que aqui se oferece, no entanto, não se coloca nesta linha de pesquisa tão profícua, mas num ponto anterior à ação missionária. A missão e o missionário católicos, independentemente de poderem estar mais ou menos associados a projetos políticos de dominação externos à própria instituição eclesiástica, enquadram-se necessária e obrigatoriamente dentro do quadro normativo, doutrinal e ideológico da Igreja, maxime do pensamento e da norma definidos centralmente, pela Santa Sé, pelos Pontífices Romanos e, pontualmente, pelos Concílios Gerais.

A Igreja Católica é, por definição, uma instituição hierarquizada, com uma hierarquia vertical, que se estende da Cátedra de S. Pedro ao mais ínfimo braço da sua orgânica, incluindo todas as suas missões.

A realidade de uma Igreja Católica missionária resulta, desde logo, do seu entendimento histórico de instituição que se afirma fundada por Deus, por meio da Sua Incarnação, Jesus Cristo. Com base nesta crença a Igreja entende-se dotada de uma mensagem universalista, própria para todas as épocas, geografias e populações, baseada numa ideia universal e global de Redenção e Salvação.

Associa a esta mensagem universalista a crença de que é sua obrigação e dever o anúncio dessa mensagem salvífica, visando a conversão do outro. Funda-se para tal nos textos dos evangelhos, que desde os primeiros tempos do cristianismo (nomeadamente a partir de S. Paulo e do seu ênfase na conversão de não-judeus) sustentaram a atividade missionária de conversão.

Este auto-entendimento da Igreja como um ente missionário expressa-se não apenas na sua múltipla atividade missionária, na vasta produção que sobre o tema a própria Igreja e os seus

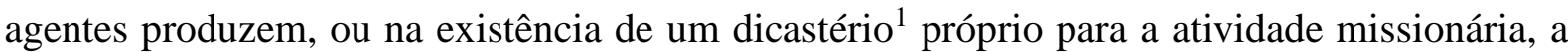
Congregação para a Evangelização dos Povos (antiga Sacra Congregatio De Propaganda Fide), mas também afirma-se nos próprios textos fundamentais com que a Igreja expõe e explica os princípios que a norteiam.

Assim, o recente Compêndio do Catecismo da Igreja Católica (que visa apresentar de modo pedagógico os princípios doutrinários contidos no Catecismo ${ }^{2}$ ) expõe de modo muito

\footnotetext{
${ }^{1}$ As Congregações Romanas constituem os dicastérios da Santa Sé, definidos como os grandes ministérios da Santa Sé para auxiliar o Pontífice no governo da Igreja, criados a partir do séc. XVI, sendo o mais antigo o da Inquisição, hoje chamado da Doutrina da Fé. O último a ser criado na Época Moderna foi precisamente o da "Propagação da Fé" (De Propaganda Fide), em 1622, diretamente vocacionado para a atividade missionária da Igreja. Cf. D'ONORIO, Joel Benoit. "Congrégations Romaines." In Dictionnaire historique de la papauté, ed. Philippe Levillain. Paris: Librairie Arthème Fayard, 1994.

${ }^{2} \mathrm{O}$ catecismo é, por natureza, um condensamento estruturado do magistério da Igreja naquilo que ela entende serem as verdades de Fé, integrando não apenas os fundamentos evangélicos da Igreja mas também o magistério 
claro o que a Igreja entende ser a sua natureza universalista e missionária, facetas interconectadas e decorrentes do que a Igreja entende ser um mandato de Cristo.

A Igreja é católica, isto é, universal, porque nela está presente Cristo: "Onde está Cristo Jesus, aí está a Igreja católica» (S. Inácio de Antioquia). Ela anuncia a totalidade e a integridade da fé; leva e administra a plenitude dos meios de salvação; é enviada em missão a todos os povos, em todos os tempos e qualquer que seja a cultura a que eles pertençam."

"Porque é que a Igreja deve anunciar o Evangelho a todo o mundo?

Porque Cristo ordenou: «ide e ensinai todas as nações, baptizando-as no nome do Pai e do Filho e do Espírito Santo» (Mt 28,19). Este mandato missionário do Senhor tem a sua fonte no amor eterno de Deus, que enviou o seu Filho e o seu Espírito porque «quer que todos os homens sejam salvos e cheguem ao conhecimento da verdade» (1 Tim 2, 4)."

Compêndio do Catecismo da Igreja Católica, n. ${ }^{\circ} 166$ e $172^{3}$

Este é, de modo muito resumido, o quadro doutrinário de base que sustenta a natureza missionária da Igreja, fundando em termos religiosos a atividade de conversão.

\section{A MISSÃO NA IGREJA ATÉ AO MAGISTÉRIO DO SÉC. XX}

Importa recordar que a atividade missionária não é, de per se, uma atividade que a Igreja desenvolva exclusivamente em contextos não-europeus e num quadro de dominação, colonial ou outra. Uma leitura completa da história missionária da Igreja implica recordar as conversões dos primeiros séculos do cristianismo (anteriores mesmo aos éditos de tolerância e de oficialização da nova religião) principalmente centradas nos territórios do Império Romano e limítrofes, passando depois às conversões dos povos das Ilhas Britânicas e do norte e leste Europeus, entre os sécs. IV e X.

Dito isto, é notório que a mais consistente e massiva atividade missionária da Igreja desenvolveu-se ao longo da época Moderna e Contemporânea, associada aos processos expansionistas dos países europeus, e frequentemente em contexto de processos de dominação colonial, direta ou indireta.

pontifício e a tradição eclesiástica, da Patrística à atualidade. O catecismo atual, preparado entre 1986 e 1992 por uma comissão de cardeais e prelados presidida pelo cardeal Ratzinger (futuro Papa Bento XVI), foi decidida pelo Papa João Paulo II, de acordo com o desejo formulado pelo Sínodo de Bispos de 1985, que pretendia um catecismo à luz do II Concílio do Vaticano. Cf. Catecismo da Igreja Católica. Coimbra: Gráfica de Coimbra, 1993.

${ }^{3}$ Catecismo da Igreja Católica: Compêndio. Coimbra: Gráfica de Coimbra, 2005. 
Numa obra clássica sobre a Igreja no expansionismo ibérico ${ }^{4}$, Boxer intuiu de modo muito claro como a autoridade Pontifícia se mantém afastada dos esforços missionários dos primeiros dois séculos, só encontrando-se a formulação de uma política missionária própria da Santa Sé a partir do séc. XVII. Os motivos são diversos, e incidem principalmente nas crises do próprio poder pontifício.

A restauração da diocese de Ceuta em 1418, a primeira ação concreta da Coroa portuguesa em matéria religiosa no período expansionista ${ }^{5}$, é concedida por um Papa Martinho V recémeleito, que inaugurava a reencontrada unidade da Igreja, saída do Cisma. Todo o séc. XV será marcado pelos receios do regresso da cisão e da expansão do Império Otomano, ao mesmo tempo que os Papas se concentram em reforçar o seu poder no palco italiano ${ }^{6}$.

O séc. XVI, por sua vez, será o século das reformas e das novas igrejas e confissões religiosas, quebrando duradouramente a unidade eclesial da cristandade ocidental europeia. Naturalmente este será o fulcro da atenção dos Pontífices quinhentistas, focados em garantir a sobrevivência do poder papal e a restauração da sua autoridade.

Nestes dois séculos os Papas, seguindo a tradicional política pontifícia de pragmatismo e o princípio do mal-menor, irão conceder às Coroa Ibéricas e a seu pedido, um conjunto de diplomas que na prática erguem os sistemas de padroado, colocando a atividade religiosa nos espaços coloniais das duas Coroas sob a autoridade e iniciativa régia, apenas com uma teórica superintendência da Santa Sé7.

Não se pode, como tal, afirmar que neste período a Igreja tivesse uma política missionária própria, antes alargava o universo dos seus crentes e as geografias da sua presença por via da atividade missionária realizada sob os auspícios de soberanos temporais que visavam, antes de mais, construir um domínio pluricontinental alicerçado (também) sobre a pertença e subordinação religiosa.

\footnotetext{
${ }^{4}$ BOXER, Charles. A Igreja e a Expansão Ibérica (1440-1770). Lisboa: Edições 70, 1981.

${ }^{5}$ Para uma visão resumida da criação da diocese de Ceuta (considerada como uma restauração, em virtude da pré-existência de uma diocese de Ceuta nos primeiros séculos do cristianismo) e seu significado veja-se FARINHA, António. "Marrocos". In Dicionário de História Religiosa de Portugal, J-P, ed. Carlos Moreira Azevedo. Rio de Mouro: Círculo de Leitores, CEHR-UCP, 2001.

${ }^{6}$ Note-se que desde o fim do cisma, em 1417, e até à eleição de João Paulo II em 1978, a Santa Sé teve apenas 3 papas não italianos: os aragoneses Calisto III Bórgia (1455-1458) e seu sobrinho Alexandre VI Bórgia (1496-1503) e o holandês Adriano VI (1522-1523). Apenas o último era estranho à Itália e à Cúria Romana, já que Calisto III serviu Afonso V de Aragão, que era também rei de Nápoles, e o seu sobrinho desenvolveu toda a carreira eclesiástica na Cúria Romana. cf. LABOA GALLEGO, Juan Maria. História dos Papas. Entre o reino de Deus e o poder terreno. Lisboa: A Esfera dos Livros, 2010.

7 Para uma visão resumida do sistema de Padroado e da sua relação com a Santa Sé, veja-se BOXER, Charles. A Igreja e a Expansão Ibérica (1440-1770). Lisboa: Edições 70, 1981, e GONÇALVES, Nuno da Silva. "Padroado". In Dicionário de História Religiosa de Portugal, J-P, ed. Carlos Moreira Azevedo. Rio de Mouro: Círculo de Leitores, CEHR-UCP, 2001.
} 
Será já passado o período tridentino, e concluindo as reformas que estão associadas ao concílio, que os Papas aparecem com a preocupação de determinarem uma política missionária própria, pensada e dirigida a partir da Santa Sé. O objetivo é antes de mais consolidar a reafirmação do poder pontifício feita pelo Concílio, e ao mesmo tempo tomar a iniciativa de atuar em geografias extraeuropeias para, como afirmava $\mathrm{Chaunu}^{8}$, obter novas almas que substituíssem as perdidas para as reformas protestantes.

A demonstração cabal é a criação em 1622, por Gregório $\mathrm{XV}$, da Congregação De Propaganda Fide, que no entanto é o culminar de um processo que se iniciara com os seus antecessores, em particular Gregório XIII, Clemente VIII e Paulo V, com iniciativas de variada natureza 9 .

A criação do dicastério missionário, e a existência prévia e sequente de numerosos documentos e provimentos pontifícios para as missões, não foi no entanto pontuado por um sistemático e consistente corpo doutrinal sobre o tema, formando um magistério dos Papas para as missões ${ }^{10}$.

\section{O MAGISTÉRIO PONTIFÍCIO PARA AS MISSÕES (1919-1959)}

Um magistério pontifício sobre as missões será particularmente uma realidade do séc. XX, com antecedentes nas encíclicas de Leão XIII Sancta Dei Civitas (1880) e Catholicae Ecclesiae (1890). A primeira louva o trabalho missionário desse século XIX e exorta os fiéis católicos à colaboração pelo apoio material e orante ${ }^{11}$; a segunda fez a condenação da escravatura (relembrando o Papa a longa carta encíclica, In Plurimis, que escrevera a 5 de Maio de 1888 ao episcopado brasileiro por ocasião da abolição da escravatura ${ }^{12}$ ) e da defesa da ação missionária em prol da libertação de escravos, especificamente em África (mencionando os esforços desenvolvidos pelo Cardeal Lavigerie), a que o Papa faz associar a

\footnotetext{
${ }^{8}$ CHAUNU, Pierre. Église, culture et société. Essais sur reforme et contre-réforme. 1517-1620. Paris: S.E.D.E.S., 1981, p. 421 e segs.

${ }^{9}$ HOFFMAN, R. "Propagation of the Faith, Congregation for the". In New Catholic Encyclopedia. Detroit: Gale, 2003. Vol. 11.

${ }^{10}$ Com magistério pontifício a Igreja entende o conjunto de documentos formais (encíclicas, constituições apostólicas, breves , exortações apostólicas, etc.) emitidos pelos Papas no exercício da sua autoridade ordinária e tendo por objetivo tocar de modo educativo e pastoral um determinado tema que os Papas desejam precisar ou aprofundar à luz da doutrina da Igreja.

${ }^{11}$ LEÃO XIII, Papa. Sôbre as Missões Católicas : Encíclicas Sancta Dei Civitas e Christi Nomen. Petrópolis: ed. Vozes, 1961.

${ }^{12}$ LEÃO XIII, Papa. Sôbre a aboliçäo da escravidão: carta encíclica "In plurimis". Petrópolis: ed. Vozes, 1963.
}

CANOA DO TEMPO - Revista do Prog. de Pós-Graduação em História. Manaus, v.10 - n², dez. 2018 
ideia de um sequente processo de conversão ao catolicismo, para o que determina o apoio material das dioceses católicas às missões, para o duplo trabalho de libertação e conversão ${ }^{13}$.

$\mathrm{O}$ corpo do magistério sobre as missões no séc. XX, nomeadamente aquele que nos ocupa aqui e que se situa entre o final da I Guerra e o II Concílio do Vaticano, apresenta-se muito mais completo, demonstrando uma sensibilidade para o tema patente no facto de todos os Papas, de Bento XV a João XXIII, terem emitido um documento magistral sobre o tema (e no caso de Pio XII, o de mais longo pontificado, dois documentos):

- 1919 - Carta apostólica Maximum Illud - Bento XV della Chiesa - "Sobre a propagação da Fé Católica no mundo inteiro"

- 1926 - Carta encíclica Rerum Eclesiae - Pio XI Ratti - "Sobre a acção missionária"

- 1951 - Carta encíclica Evangelii Precones - Pio XII Pacelli - "Sobre o fomento das Missões"

- 1957 - Carta encíclica Fidei Donum - Pio XII Pacelli - "Sobre a situação das missões católicas, particularmente da África"

- 1961 - Carta encíclica Princeps Pastorum - João XXIII Roncalli - "Sobre as Missões Católicas"

Estes 5 documentos, emitidos pelos Papas num hiato temporal de 40 anos, são a base de um magistério para as Missões que se estabelece numa época que faz a ponte de um mundo colonizado para um mundo em descolonização, ultrapassando no permeio o período histórico de máxima afirmação das teorias raciais e da violência racial.

O ponto mais relevante a salientar no magistério destes anos, e marcando precisamente esta realidade histórica de mudança de paradigmas pautada pelas duas guerras mundiais e pela vaga de descolonização, é o da transposição gradual do modelo pastoral missionário, baseado num clero e episcopado europeus, para o modelo diocesano, assente num clero e episcopado local, com a plenitude da autoridade pastoral e eclesiástica que os bispos e o seu clero exercem nas suas circunscrições eclesiásticas.

Estamos perante, no que à África e à Ásia diz respeito, do cumprimento de um ideal que vemos formulado desde pelo menos os finais do séc. $X V^{14}$, da constituição de um clero próprio das terras de missão, a quem fossem entregues as novas Igrejas.

13 LEÃO XIII, Papa. Carta Encíclica Catholicae Ecclesiae. 1890. Disponível em: http://w2.vatican.va/content/leo-xiii/la/encyclicals/documents/hf_l-xiii_enc_20111890_catholicaeecclesiae.html. Consultada a 10/10/2018

CANOA DO TEMPO - Algumas considerações sobre o Magistério Pontifício para as missões anterior ao II Concílio Do Vaticano (1919-1959). 
Este desiderato, da constituição de uma Igreja local, baseada na autoridade do Bispo diocesano e do seu clero, mais não é do que o culminar do processo de constituição de comunidades católicas, de acordo com um padrão que remonta aos primeiros tempos do cristianismo.

Depois de um período inicial de atuação missionária, visando a conversão da população de uma determinada região, e depois de constituída uma comunidade com dimensão e solidez humana e material, da qual saiam vocações religiosas suficientes, a Igreja forma uma nova unidade eclesial, a diocese, dotada de autoridade e autonomia personificada no seu bispo ${ }^{15}$.

Este processo seria o que o rei D. Manuel I de Portugal (1495-1521) teria em mente para a "nova cristandade do Congo", pensando a constituição de um clero e a formação de um episcopado congolês, retirado naturalmente da sua elite, e que viesse eventualmente a assumir a liderança de uma igreja diocesana.

Este processo, que nos parece ter sido travado pela morte deste Rei, e a sua sucessão por um D. João III bem menos afeito à ideia de um alto clero africano que tomasse em mão as circunscrições eclesiásticas que viria a obter da Santa $\operatorname{Sé}^{16}$, fez que o Bispo D. Henrique, filho do Manicongo D. Afonso I (Nzinga Mbemba), ficasse como o único bispo africano sagrado antes do séc. $\mathrm{XX}^{17}$.

A partir de D. João III ficou firmado o pensamento de que as dignidades eclesiásticas (e como tal o controlo da Igreja nos territórios coloniais) estariam nas mãos do clero europeu, a quem preferencialmente estaria entregue qualquer outra iniciativa religiosa. Era o tempo das construções raciais ${ }^{18}$.

O magistério dos Papas no séc. XX irá no sentido oposto, acompanhando o ocaso dos impérios coloniais. Fazendo jus à sua política de pragmatismo, os Papas farão evoluir a

${ }^{14}$ Sobre esta questão, e além da clássica formulação de Charles Boxer, (BOXER, Charles. A Igreja e a Expansão Ibérica (1440-1770). Lisboa: Edições 70, 1981), no contexto da expansão peninsular e da missão sob o padroado; veja-se o que digo sobre a questão para o reino do Congo no meu trabalho doutoral FALCÃO, Nuno de Pinho. "Ecclesia Semper Reformanda". A Congregação dos Lóios e a Reforma da Igreja (Itália, Portugal e África - 1404/1580). Porto: CITCEM/ Edições Afrontamento, 2018. Recentemente Francisco Bethencourt (BETHENCOURT, Francisco. Racismos, das cruzadas ao século XX. Lisboa: Temas e Debates, 2015), toca na questão e coloca-a no contexto das relações raciais associadas à expansão portuguesa, nomeadamente para justificar a falência de qualquer projeto de constituição de um clero africano forte.

${ }^{15}$ Sobre os bispos, e o grau de autonomia e de autoridade que lhes pertence na orgânica eclesiástica, veja-se QUINN, A. "Bishop, Diocesan. Canon Law". In New Catholic Encyclopedia. Detroit: Gale, 2003. Vol. 2; WOOD, Susan. "Bishop (In the church)". In New Catholic Encyclopedia. Detroit: Gale. 2003. Vol. 2, e WOOD, Susan. "Bishop (Sacramental Theology Of)". In New Catholic Encyclopedia. Detroit: Gale, 2003. Vol. 2.

${ }^{16}$ D. João III obtém do Papa Paulo III a constituição das dioceses, de Goa, de Cabo Verde, de S. Tomé e Príncipe, de Angra e Ilhas dos Açores e de S. Salvador da Bahia.

${ }^{17}$ Sobre esta questão, veja-se o que digo em FALCÃO, Nuno de Pinho. "Ecclesia Semper Reformanda". A Congregação dos Lóios e a Reforma da Igreja (Itália, Portugal e África - 1404/1580).

${ }^{18}$ Matéria que tanto BOXER, Charles. A Igreja e a Expansão Ibérica (1440-1770), como BETHENCOURT, Francisco. Racismos, das cruzadas ao século XX. acentuam bem. 
questão missionária de acordo com as mudanças políticas, podendo por fim atingir o ponto em que se apresenta a constituição de Igrejas locais como a plenitude de qualquer ação missionária e se defende uma Igreja e clero locais à imagem da sua própria cultura, e não do modelo romano que anteriormente se pretendia impor.

Não se pretende com isto afirmar que a ação dos Papas nesta matéria tenha sido apenas ditada pela força das circunstâncias e das mudanças dos tempos. A Igreja, como qualquer organismo vivo, sofre com as transformações, às quais se adapta. No entanto é notório, no magistério e nas ações dos Papas, alguns dados que apontam para uma adaptação mais concreta e rápida do que aquela que foi assumida pelas potências coloniais, e em alguns casos constituindo-se mesmo como afirmações para um mundo ainda fortemente preso a preconceitos de raça.

Em 1935 o governo nazi da Alemanha publicou a célebre lei de pureza racial, visando todos os povos considerados inferiores e ameaça à herança racial alemã. Marca-se assim um regime de Estado definido racialmente, que não apenas irá viver sob o efeito da exclusão, como praticará sistematicamente a destruição física dos indivíduos ${ }^{19}$.

A consolidação do regime, bem como a aparente conformidade geral com o seu pensamento (nomes de críticos, como o arcebispo Von Galen, são raros) espelham bem o triunfo das teorias raciais, não apenas na Europa mas nos países por ela dominados.

Quatro anos volvidos, a 29 de outubro de 1939, e no contexto das primeiras vitórias da Alemanha numa II Guerra Mundial que não conta ainda sequer 2 meses, a Basílica do Vaticano foi o palco da sagração episcopal do ugandês Joseph Kiwánuka ${ }^{20}$.

O sagrante foi o recém-eleito Papa Pio XII, e os co-sagrantes os Arcebispos Celso Costantini, Secretário da Propaganda Fide, e Henri Streicher, missionário da Sociedade dos Missionários de África e antigo vigário apostólico no Uganda ${ }^{21}$.

O Papa, em plena explosão de violência alicerçada em ideologia de raça e de dominação, dá um sinal muito claro ao sagrar pessoalmente o primeiro bispo africano católico e de rito latino desde D. Henrique do Congo em 1518, e constituindo-se os dois como casos singulares desde a antiguidade tardia.

Pio XII coloca assim Monsenhor Kiwánuka na sucessão da sua própria linhagem episcopal $^{22}$, a qual certamente previa transmitir aos futuros prelados africanos que este novo

\footnotetext{
${ }^{19}$ Idem, ibidem.

${ }^{20}$ Sobre o Bispo Kiwánuka veja-se, por exemplo, WALLIGO, John Mary. A History of African Priests. Nairobi: Matianum Press Consultants, 1988.

${ }^{21}$ Cf. Archbishop Joseph Kiwánuka, M. Afr. In "The Catholic Hierarchy", disponível em linha em: http://www.catholic-hierarchy.org/bishop/bkiwa.html, consultado a 10/10/2018.

LCANOA DO TEMPO - Algumas considerações sobre o Magistério Pontifício para as missões anterior ao II Concílio Do Vaticano (1919-1959).
} 
bispo sagraria, unindo ainda mais estreitamente esse futuro episcopado africano à Santa Sé e ao Colégio Episcopal ${ }^{23}$.

Kiwánuka era membro da Sociedade dos Missionários de África, doutor em Direito Canónico pela Pontifícia Universidade de S. Tomás de Aquino de Roma, tendo sido eleito a 25 de Maio de 1939 Vigário Apostólico de Masaka, uma escolha de Pio XII no segundo mês do seu pontificado, dando à Igreja do Uganda um bispo natural do país ${ }^{24}$.

A escolha deste novo bispo não foi fortuita, ainda mais que o Papa Pio XII estava, desde muito antes da sua eleição, ligado ao governo da Santa Sé, como núncio ou Secretário de Estado. Vem na sucessão dos esforços de criação e alargamento em África de um clero que tomasse em mãos as responsabilidades pastorais dos territórios que, sob dominação política europeia, eram palco de intensa atividade missionária.

\section{O MAGISTÉRIO E A FORMAÇÃO DO NOVO CLERO}

Esta ideia da necessidade de formar um clero local tinha o seu principal suporte teórico na Carta Apostólica Maximum illud, de 30 de Novembro de 1919, em que no rescaldo da I Guerra Mundial o Papa Bento XV elencava as necessidades prementes da atividade missionária católica, destacando no ponto $7^{\circ}$ (dedicado ao cuidado e formação do clero nativo) a ideia de que seria a esperança das Igrejas jovens ${ }^{25}$.

Para o Papa, e na sequência do processo de conversão e introdução ao universo católico promovido em contexto de missão, seguir-se-ia naturalmente a constituição de administrações eclesiásticas (paróquias, prelazias e dioceses), entregues aos cuidados do clero missionário, seguindo-se o desenvolvimento de vocações entre os convertidos, formando a base de um clero nativo.

O Papa sublinha que a formação deste clero não visava a constituição de um mero auxiliar do clero europeu, mas que era um fim estrutural da ação missionária ${ }^{26}$. Bento XV acentua

${ }^{22}$ Por linhagem episcopal entende-se a sucessão de sagração entre bispos católicos, ou seja a linha histórica que une cada bispo sagrado ao seu sagrante e por aí sucessivamente. É formalmente de grande importância porque diretamente ligado à validade dessa sagração, pois um bispo só pode ser sagrado por um outro prelado, que esteja em comunhão com a Santa Sé e tenha por sua vez recebido uma sagração válida. No extremo, e em matéria doutrinal, acredita-se que o ato de sagração transmite, por via da imposição de mãos, a substância do Espírito. Pela sagração, e através do sagrante, o novo prelado une-se ao colégio episcopal, que a Igreja apresenta como sucessão direta dos Apóstolos. Cf. WOOD, Susan. "Bishop (In the church)".

${ }^{23}$ De facto o Arcebispo Kiwánuka foi sagrante de um bispo ugandês e co-sagrante principal de dois bispos franceses, um ruandês e um tanzaniano.

${ }^{24}$ Sobre a Igreja do Uganda veja-se FAUPEL, John. Uganda, The Catholic Church in. In "New Catholic Encyclopedia". Detroit: Gale, 2003.

${ }^{25}$ BENTO XV, Papa. Maximum illud. Cucujães: Editorial Missões, 1961

${ }^{26}$ Sobre esta questão, e atendendo que mesmo em questões de magistério pontifício dirigido ao clero católico nem sempre a prática segue de imediato a teoria, pode-se convocar o testemunho do comboniano Padre Graciano 
vivamente a questão da formação do clero nativo, sustentando mesmo que nas regiões do mundo onde a presença missionária contava já com séculos de existência e onde ainda não se podia encontrar um clero local abundante e bem formado, tal seria consequência de uma deficitária formação desses clérigos.

Não discutindo esta leitura causal do pontífice, a que se poderia juntar muitos outros nexos de causalidade que não apenas o do mau funcionamento dos seminários e outros centros de formação de clérigos em territórios de missão, retenha-se fundamentalmente o desejo de Bento XV em centrar os esforços de constituição de um clero nativo no aperfeiçoamento do processo formativo, para o que o Papa irá ordenar à Congregação De Propaganda Fide que aplique as medidas necessárias em cada região missionária, fundando ou reformando seminários.

Pretendia Bento XV que o clero nativo fosse formado com o grau de exigência aplicado ao clero europeu, perspetivando-se que viesse a assumir por si (quando formado em qualidade e quantidade) a direção espiritual dos seus povos e o governo das suas Igrejas. Como o Papa sustentava : “...Com efeito, onde o clero indígena é suficiente e se encontra tão bem formado que não desmerece em nada a sua vocação, pode-se dizer que a obra do missionário está felizmente acabada e a Igreja perfeitamente estabelecida"27.

A 28 de Fevereiro de 1926 o Papa Pio XI Ratti, na senda do antecessor, promulga a Carta Encíclica Rerum Ecclesiae ${ }^{28}$, em que louva o crescimento missionário verificado após a Maximum illud, reafirma a obrigação dos fiéis e do clero na promoção das missões católicas, e reforça substancialmente o apelo à formação do clero nativo dos territórios de missão, para o que vai determinar de modo pormenorizado a constituição de seminários, a organização de comunidades de ordens e congregações religiosas, e incentivando mesmo a introdução de ordens contemplativas.

A atenção pormenorizadora que Pio XI dá à formação de clérigos nativos, instituição de seminários, introdução de comunidades monásticas e conventuais e organização administrativa do território eclesiástico, permite-nos perceber que entre as duas encíclicas assistimos a um avanço da atuação missionária, particularmente em África e na Ásia, dirigida

Castellari, que nas suas memórias de missionário em Moçambique recorda como, nos idos da década de 1960, havia diferença de posição e tratamento entre os sacerdotes portugueses e os moçambicanos, a quem caberia apenas as coadjutorias. Cf. CASTELLARI, Graciano, MCCJ (autor); SANTOS, Patrícia Teixeira Santo; FALCÃO, Nuno de Pinho (editores). "Deboli tra deboli". Memórias de um missionário em Moçambique, 1964-2005. Porto: Centro de Estudos Africanos da Universidade do Porto, 2015, p. 30 e 31.

${ }^{27}$ BENTO XV, Papa. Maximum illud.

${ }^{28}$ PIO XI, Papa. Rerum Ecclesiae. Cucujães: Editorial Missões, 1961. 
para a constituição de uma Igreja local perfeitamente estruturada e dotada das instituições que definem os quadros que demarcam as dioceses.

Este avanço exponencial das missões católicas no período do pós-guerra, em particular no que se refere ao sistemático estabelecimento de um clero local, estará patente (por exemplo) na sagração do primeiro bispo asiático em $1923^{29}$, a que se seguirá em 1939 a de Monsenhor Kiwánuka.

O papel da encíclica de Pio XI será salientado e retomado com a Encíclica Evangelii Praecones $^{30}$ (2 de Junho de 1951), com que Pio XII comemora o seu vigésimo quinto aniversário. O Papa Pacelli, além de mencionar todos os avanços missionários que se seguiram ao magistério de Bento XV e Pio XI, reflete sobre as dificuldades do trabalho missionário, mencionando particularmente as perseguições religiosas sofridas e acentuando a finalidade da missão como criadora de uma Igreja local ${ }^{31}$.

Se esta preocupação está na linha com o magistério dos seus antecessores, não deixa Pio XII de introduzir algumas preocupações novas sobre o papel dos leigos, bem como o papel social e assistencial da Igreja nas missões e, com alguma acuidade, uma chamada de atenção para o respeito e preservação da cultura própria das regiões de missão, que apesar de Pio XII limitar aos aspetos que não fossem contrários ao espírito cristão, revela a alteração de preocupações num mundo em transformações políticas notórias, nomeadamente nos territórios missionários da África e da Ásia.

O empenho do Papa Pacelli na promoção da atividade missionária, bem como o reforço da ideia patente no magistério de que a missão não é apenas um esforço das Congregações missionárias, mas um empenho e dever moral de todos os clérigos e fiéis, fica patente na sua

${ }^{29}$ Como mencionado na encíclica Princeps Pastorum (JOÃO XXIII, Papa. Princeps Pastorum. Lisboa: Morais editora, 1960). Tratar-se-á do jesuíta Francis Tiburtius Roche, que Pio XI em 1923 nomeou bispo da nova diocese de Tuticorin, na Índia, sendo o primeiro bispo indiano de rito latino (cf. SANTOS HERNANDEZ, Ángel, SJ - Jesuitas e Obispados. Los Jesuitas Obispos misioneros y los Obispos jesuítas de la extinción. Madrid: Universidad Pontificia Comillas; 2000. Vol. II., p. 217 e 218). Tal como no caso africano, a afirmação do Papa apenas corresponde a prelados católicos da época contemporânea, descartando os exemplos históricos de prelados africanos e asiáticos eleitos na época moderna, certamente devido ao carácter episódico destas nomeações. De facto, bispo asiático de rito latino pode-se encontrar, pelo menos, a eleição e consagração episcopal em 1685, do dominicano chinês, Luo Wenzao, bispo de Nanquim cf. SAN ROMÁN, Miguel Angel. "Luo Wenzao: A unique role in the seventeen century Church of China". In Missionary Approaches and linguistics in mainland China and Taiwan. Lovaina: Leuven University Press, 2001, p. 133 e segs.

${ }^{30}$ PIO XII, Papa. Evangelii praecones : carta encíclica de Sua Santidade Pio XII para fomentar as missões. Lisboa: União Missionária do Clero, 1951.

31 “... A primeira finalidade das missões é, porém, como todos sabem, que a luz do cristianismo brilhe com maior esplendor ante os novos povos e faça surgir dentre eles novos cristãos. Mas é preciso também que procurem desde logo - e o tenham sempre presente como fito - estabelecer solidamente a Igreja entre os povos evangelizados, dando-lhes uma hierarquia própria, formada de elementos nativos.", cf. idem, ibidem, ponto 5.22 . 
Encíclica Fidei Donum, de $1957^{32}$, a mesma em que o Papa introduz o termo "Igrejas novas" para identificar as Igrejas formadas em territórios de missão.

Nesta encíclica, além de reforçar o magistério tradicional, nomeadamente a ideia dos três deveres de toda a Igreja para com a missão (oração, esmola e vocações) o Papa exorta os bispos a promoverem as vocações missionárias, nomeadamente entre o seu clero. $\mathrm{O}$ alcance mais profundo desta encíclica será precisamente o aparecimento dos missionários fidei donum, sacerdotes diocesanos que se oferecem para trabalhar nas missões, num determinado período de tempo.

As leituras que Pio XI e Pio XII fizeram sob a importância da formação do clero local e a sua ligação ao sucesso da atuação missionária e ao estabelecimento de uma Igreja local, são as que estabelecerá o Papa João XXIII na sua Carta Encíclica Princeps Pastorum ${ }^{33}$, sobre as missões católicas. Este texto, datado de 28 de Novembro de 1959, comemora o quadragésimo aniversário da carta apostólica de Bento XV, e publica-se nas vésperas da abertura do II Concílio do Vaticano, cuja intenção o Papa Roncalli anunciara à Cúria nos primeiros dias desse ano.

Com esta encíclica, a última que sobre o tema se emite antes do Concílio, João XXIII soma-se ao magistério, desde logo ilustrando numericamente o rápido crescimento das Igrejas de Missão desde 1919, sustentado no crescimento dos números de sacerdotes ordenados e de bispos sagrados.

Considerando o hiato de tempo que medeia entre a Maximum illud e a Princeps Pastorum, o Papa Roncalli faz notar que se em 1918 podíamos encontrar 919 padres asiáticos e 90 africanos, que em 1957 tinham-se multiplicado até atingirem as cifras de 5553 sacerdotes asiáticos e 1811 africanos. No que se refere ao número de prelados a Ásia contará, entre 1923 e 1959, a eleição de 68 bispos, enquanto África, entre 1939 e 1959, passará a contar com 25 prelados do continente.

A este dado poder-se-á certamente somar, ainda que o Papa não o faça, a constituição de novas dioceses. Apenas tomando alguns exemplos da África lusófona, então ainda sob dominação colonial portuguesa, vemos que Moçambique, uma prelazia territorial até 1940, passa a dividir-se eclesiasticamente em 3 dioceses, que se multiplicam nas décadas seguintes; e que Angola segue precisamente o mesmo figurino de Moçambique, passando em 1940 de

\footnotetext{
32 PIO XII, Papa. Fidei Donum. carta aos bispos de Moçambique e Angola. Lisboa: União Missionária do Clero, 1958.

${ }^{33}$ JOÃO XXIII, Papa. Princeps Pastorum. 
diocese única a 3 dioceses, multiplicadas futuramente ${ }^{34}$. São novas dioceses que, originalmente providas em bispos portugueses, terão (na sequência das independências de 1975) provimentos em bispos moçambicanos e angolanos.

Se Bento XV, Pio XI e Pio XII salientavam a necessidade de garantir o futuro das Igrejas de missão pela formação cuidada e exigente de um clero local digno, João XXIII reforça e aprofunda este ponto do magistério pontifício, introduzindo porém algumas mudanças significativas, próprias de um mundo em descolonização.

Depois de acentuar os notórios progressos das últimas décadas no terreno missionário, o Papa foca particularmente a questão da constituição de uma verdadeira hierarquia e um clero local nas Igrejas de missão, sendo significativo que esta questão, que na Maximum Illud correspondia ao ponto sétimo ponto, ocupe com João XXIII o primeiro e segundo pontos

Demonstrando a centralidade que a constituição nas novas Igrejas locais, servidas por um episcopado e clero próprios, tinha agora no magistério, seguindo as alterações políticas e de paradigmas de um mundo que caminhava a passos largos para os processos de descolonização, o Papa Roncalli determina (uma novidade no que se refere ao magistério anterior) que a formação dos clérigos nas Igrejas novas seja feita tendo em vista o mesmo rigor e finalidade que a dos seus colegas de Igrejas mais antigas, mas adaptando-se e incorporando os elementos culturais e ambientais, bem como os quadros de valores próprios de cada território, de que os futuros clérigos serão pastores.

O Concílio que João XXIII convocou deu origem, ele mesmo, a um documento sobre as missões que pertence não já ao magistério pontifício, mas ao magistério conciliar: o decreto conciliar Ad Gentes $^{35}$, que Paulo VI promulgou a 7 de Dezembro de 1965.

O novo documento introduz, nesta questão do magistério da Igreja para as missões, uma teorização doutrinal e uma determinação prática muito profundas, que não apenas recolhe e atualiza exponencialmente o magistério anterior, como apresenta a missão católica segundo os desafios que eram apresentados pela realidade da década de 1960.

O resultado será a renovação da missiologia e da própria atividade missionária, que será depois transposta ao magistério dos Papas sequentes. Herdeiro de todo o magistério anterior, o decreto conciliar, com todo o seu peso, não é um documento fundador, mas um ponto de renovação no pensamento e atuação missionários, alicerçado na tradição eclesial, mas

\footnotetext{
${ }^{34}$ Para as transformações da Igreja de Moçambique e Angola vejam-se CORREIA, Francisco Augusto da Cruz. "Moçambique". In Dicionário de História Religiosa de Portugal, J-P, ed. Carlos Moreira Azevedo. Rio de Mouro: Círculo de Leitores, CEHR-UCP, 2001, p. 236 a 247; GONÇALVES, António Custódio e SANTOS, Maria Emília Madeira. "Angola." In Dicionário de História Religiosa de Portugal, A-C, ed. Carlos Moreira Azevedo. Rio de Mouro: Círculo de Leitores, CEHR-UCP, 2000, p. 51 a 67.

${ }^{35}$ Ad Gentes. São Paulo: Edições Paulinas, 1966.
} 
necessariamente aberto aos novos tempos, próprio de um documento que se insere no processo de aggiornamento da Igreja.

\section{CONSIDERAÇÕES FINAIS}

A tentativa de compreender e enquadrar a atividade missionária católica das últimas décadas do séc. XIX à atualidade não poderá, nunca, excluir uma leitura do que foi o pensamento da cúpula da própria Igreja sobre o tema, expresso no corpo do magistério pontifício e conciliar.

Este trabalho, que olha o magistério pontifício para as missões de Bento XV a João XXIII, mais não salientou que alguns dados centrais do pensamento contemporâneo da Igreja sobre a missão, em particular o entendimento óbvio, mas relevante, do fim último da missão como o de constituir uma cristandade completa e perfeita, pela formação de uma Igreja local assente na existência de uma circunscrição eclesiástica, dotada de prelados e clérigos locais que servem uma população que se reconhece e afirma como católica. Para este fim os Papas salientam a importância da formação destes eclesiásticos como garantes destas novas Igrejas, preocupação constante no tempo e que apenas se adapta na formulação.

Ao historiador das missões caberá assim descortinar como o magistério, pensado e emitido a partir da Santa Sé, produzido com base em informação privilegiada e centralizada mas frequentemente distante da realidade efetiva das missões, com a força de influenciar as grandes decisões e dotado de um peso universalista que a autoridade papal the concede, influencia e é influenciado não apenas pelas circunstâncias gerais do mundo, mas pelas da atividade missionária em particular.

\section{Recebido em: 21/10/2018 Aceito em: 17/12/2018}

\section{REFÊRENCIAS BIBLIOGRÁFICAS}

Ad Gentes. São Paulo: Edições Paulinas, 1966.

Archbishop Joseph Kiwánuka,. In "The Catholic Hierarchy", disponível em: http://www.catholic-hierarchy.org/bishop/bkiwa.html, Consultada a 10/10/2018.

BENTO XV, Papa. Maximum illud. Cucujães: Editorial Missões, 1961

BETHENCOURT, Francisco. Racismos, das cruzadas ao século XX. Lisboa: Temas e Debates, 2015.

BOXER, Charles. A Igreja e a Expansão Ibérica (1440-1770). Lisboa: Edições 70, 1981. 
CASTELLARI, Graciano, MCCJ (autor); SANTOS, Patrícia Teixeira Santo; FALCÃO, Nuno de Pinho (editores). "Deboli tra deboli". Memórias de um missionário em Moçambique, 1964-2005. Porto: Centro de Estudos Africanos da Universidade do Porto, 2015.

Catecismo da Igreja Católica. Coimbra: Gráfica de Coimbra, 1993.

Catecismo da Igreja Católica: Compêndio. Coimbra: Gráfica de Coimbra, 2005.

CHAUNU, Pierre. Église, culture et société. Essais sur reforme et contre-réforme. 15171620. Paris: S.E.D.E.S., 1981.

CORREIA, Francisco Augusto da Cruz. "Moçambique”. In Dicionário de História Religiosa de Portugal, J-P, ed. Carlos Moreira Azevedo. Rio de Mouro: Círculo de Leitores, CEHRUCP, 2001.

D'ONORIO, Joel Benoit. "Congrégations Romaines." In Dictionnaire historique de la papauté, ed. Philippe Levillain. Paris: Librairie Arthème Fayard, 1994.

FALCÃO, Nuno de Pinho. "Ecclesia Semper Reformanda”. A Congregação dos Lóios e a Reforma da Igreja (Itália, Portugal e África - 1404/1580). Porto: CITCEM/ Edições Afrontamento, 2018.

FARINHA, António. "Marrocos". In Dicionário de História Religiosa de Portugal, J-P, ed. Carlos Moreira Azevedo. Rio de Mouro: Círculo de Leitores, CEHR-UCP, 2001.

FAUPEL, John. Uganda, The Catholic Church in. In "New Catholic Encyclopedia". Detroit: Gale, 2003.

GONÇALVES, António Custódio e SANTOS, Maria Emília Madeira. "Angola." In Dicionário de História Religiosa de Portugal, A-C, ed. Carlos Moreira Azevedo. Rio de Mouro: Círculo de Leitores, CEHR-UCP, 2000.

GONÇALVES, Nuno da Silva. "Padroado". In Dicionário de História Religiosa de Portugal, J-P, ed. Carlos Moreira Azevedo. Rio de Mouro: Círculo de Leitores, CEHR-UCP, 2001.

HOFFMAN, R. "Propagation of the Faith, Congregation for the". In New Catholic Encyclopedia. Detroit: Gale, 2003. Vol. 11

JOÃO XXIII, Papa. Princeps Pastorum. Lisboa: Morais editora, 1960.

LABOA GALlegO, Juan Maria. História dos Papas. Entre o reino de Deus e o poder terreno. Lisboa: A Esfera dos Livros, 2010.

LEÃO XIII, Papa. Carta Encíclica Catholicae Ecclesiae. 1890. Disponível em: http://w2.vatican.va/content/leo-xiii/la/encyclicals/documents/hf_l-

xiii_enc_20111890_catholicae-ecclesiae.html. Acesso em: 10 de outubro de 2018. 
LEÃO XIII, Papa. Sôbre a aboliçäo da escravidão: carta encíclica "In plurimis". Petrópolis: ed. Vozes, 1963.

LEÃO XIII, Papa. Sôbre as Missões Católicas : Encíclicas Sancta Dei Civitas e Christi Nomen. Petrópolis: ed. Vozes, 1961.

PIO XI, Papa. Rerum Ecclesiae. Cucujães: Editorial Missões, 1961.

PIO XII, Papa. Evangelii praecones : carta encíclica de Sua Santidade Pio XII para fomentar as missões. Lisboa: União Missionária do Clero, 1951.

PIO XII, Papa. Fidei Donum. carta aos bispos de Moçambique e Angola. Lisboa: União Missionária do Clero, 1958.

QUINN, A. "Bishop, Diocesan. Canon Law”. In New Catholic Encyclopedia. Detroit: Gale, 2003. Vol. 2

SAN ROMÁN, Miguel Angel. "Luo Wenzao: A unique role in the seventeen century Church of China". In Missionary Approaches and linguistics in mainland China and Taiwan. Lovaina: Leuven University Press, 2001.

SANTOS HERNANDEZ, Ángel, SJ - Jesuitas e Obispados. Los Jesuitas Obispos misioneros y los Obispos jesuítas de la extinción. Madrid: Universidad Pontificia Comillas; 2000. Vol. II. WALligO, John Mary. A History of African Priests. Nairobi: Matianum Press Consultants, 1988.

WOOD, Susan. “Bishop (In the church)”. In New Catholic Encyclopedia. Detroit: Gale. 2003. Vol. 2.

WOOD, Susan. "Bishop (Sacramental Theology Of)". In New Catholic Encyclopedia. Detroit: Gale, 2003. Vol. 2 